\title{
The Principle of Solvency as a Consideration for Judge in Solving Bankruptcy Case in Indonesia
}

\author{
Boedi Haryantho $^{1} \quad$ M. Hadi Shubhan ${ }^{2} \quad$ M. Zaidun ${ }^{2}$ \\ 1.Doctoral Student of Law of Airlangga University \\ 2.Lecturer of Law Faculty of Airlangga University
}

\begin{abstract}
The present research is conducted in order to elaborate philosophical landscape in regard to the implementation of solvency principal due to the enforcement of Bankruptcy Act in Indonesia. Furthermore, the present study also tries to examine legal protection toward solvent debtor that holds good principal. The results showed that the philosophical foundation of insolvency testing is not applied within Indonesian law since legal debt system in Indonesia is quite easy. Simplicity of debt system in Indonesia since it will potentially be detrimental to many creditors because the proof can no longer be done simply. Legal protection for solvent debtors in good faith is obtained repressively by proving before the trial that the debtor is still in a solvent condition.
\end{abstract}

Keywords: Bankruptcy, Solvency, Good Faith

DOI: $10.7176 / J L P G / 96-03$

Publication date: April $30^{\text {th }} 2020$

\section{INTRODUCTION}

Bankruptcy is a confiscation and execution of all debtors' wealth that is dedicated to divide the assets to repay debtors' debts to their creditors in a balanced way or pari passu, unless there are creditors who hold the privilege to take precedence. ${ }^{1}$ Bankruptcy is a situation where the debtor is unable to make payments on debts to his/her creditors.

Solving the problem of accounts receivable debt is the main national goal in order to fulfill the economy quickly and efficiently, therefore bankruptcy arrangements are very important to be implemented in order to solve problems related to debt payment obligations immediately. ${ }^{2}$ Generally, every company has a debt. For a company, debt is not a bad thing as long the company is able to pay back the debt. This kind of company can be regarded as solvent company since this company is able to pay back all the debts. Conversely, if a company that no longer has the ability to pay its debts is called insolvent, which means not being able to pay. ${ }^{3}$ Inability to pay is mostly due to financial difficulties (financial distress) due to business debtors who have suffered setbacks.

Bankruptcy to a good legal subject of the company (natuurlijke persoon, individual insolvency) as well as legal entities or companies (rechtspersoon, corporate insolvency) can occur if some of the requirements formulated in Article 2 paragraph (1) of Law Number 37, 2004 concerning Bankruptcy and Suspension of Debt Payment Obligations can be fulfilled (Indonesian Bankruptcy Law), for instance there are at least two or more creditors and do not pay off at least one debt that is due and can be billed. These requirements without differentiating whether the debtor is simply not willing to pay the creditor because of certain reasons, for example if a creditor does not carry out the achievements that have been promised before, or it is true that the debtor is in a state of being unable to pay his debts (insolvent). ${ }^{4}$

Noting the bankruptcy requirements as determined in Article 2 paragraph (1) of Indonesian Bankruptcy Law, whereas bankruptcy law in this case does not prohibit and regulate the possibility of bankruptcy of debtors who still have enough wealth to pay their debts. This can be detrimental to companies that were actually still in a state of solvency when the Commercial Court ruled in bankruptcy. This condition can occur because of the Bankruptcy Law in Indonesia implement this regulation.

Article 2 paragraph (1) of Indonesian Bankruptcy Law does not require conditions or anything other than these two things, including not requiring debtor solvency. It means that if the judge only uses the two-parameters, he/she cannot be blamed and has even implemented the provisions of the law. Even in the provisions of Article 8 paragraph (4) of Indonesian Bankruptcy Law requires judges to grant the bankruptcy petition.

However, judges are not just mouth or mouthpiece of the Act (bouche de la loi) therefore the judge in deciding a case must prioritize the principle of proportional justice. Judges in carrying out their duties must decide based on the rule of law and consider the actions that occur regarding the law to be applied. Judges are required to dig behind the legal provisions and legal principles written in the rule of law. ${ }^{5}$

\footnotetext{
'Bagus Irawan, Aspek-aspek Hukum Kepailitan, Perusahaan, dan Asuransi, Alumni, Bandung, 2007, p. 19.

${ }^{2}$ Robintan Sulaiman dan Joko Prabowo, Lebih Jauh Tentang Kepailitan, Delta Citra Grafindo, Karawaci, 2000 , p. 1.

${ }^{3}$ Zaeni Asyhdie, Hukum Bisnis "Prinsip dan Pelaksanaannya di Indonesia”, Raja Grafindo Persada, Jakarta, 2005, p. 1.

${ }^{4}$ Gunawan Widjaja, Tanggung Jawab Direksi atas Kepailitan Perseroan, Raja Grafindo Persada, Jakarta, 2003 , p. 83-84.

${ }^{5}$ Hatta Isnaini Wahyu Utomo, "The Existence of the Notary and Notarial Deeds within Private Procedural Law in the Industrial Revolution era 4.0", International Journal of Innovation, Creativity and Change, Volume 10, Issue 3, 2019, p. 130
} 
Application of bankruptcy law in this case Article 2 paragraph (1) of Indonesian Bankruptcy Law by a commercial court judge legally, textually and synchronously, can cause new issues that are more complex and create injustice in certain cases, as in cases of bankruptcy against highly solvent debtors in the bankruptcy case above. This is where the need for restrictions for certain cases. Therefore, the solvency of the company must be considered by the judge who decides the bankruptcy request.

\section{RESEARCH PROBLEMS}

1. What are the forms of philosophical foundation of Solvency that do not apply to Bankruptcy Law in Indonesia?

2. What are the forms of legal protection for solvent debtors that hold good faith?

\section{RESEARCH METHOD}

The present study uses normative legal research methods conducted to find solutions in regard to the existing legal problems. The research approaches used in the present study are the law approach (statute approach) and conceptual approach (conceptual approach).

\section{DISCUSSION}

\section{Philosophical Basis for Insolvency Test Not Implemented in Indonesia}

Indonesian Bankruptcy Law tends to make it easier for creditors to apply for bankruptcy. Request for bankruptcy on the condition that the debts are due, collectible and it has two creditors can be taken into consideration by the judge in deciding the status of the proposed bankruptcy. In addition, accompanied by the principle of simple proof makes debtors easier to be regarded as bankrupt.

Debtors find it difficult to defend themselves in Indonesian Bankruptcy Law. Moreover, debtor financial condition is not seen as a consideration regarding this regulation. It is often seen as the origin of injustice for debtors because of problems between creditors and debtors in bankruptcy matters sometimes it is not caused by the reason the debtor is unable to pay but the debtor does not want to pay because there is a civil dispute regarding the implementation of the agreement between the debtor and creditor. Hadi Subhan argues that Bankruptcy is a condition where the debtor is unable to make payments on debts of his/her creditors. The situation of being unable to pay is usually caused by financial difficulties (financial distress) from debtor businesses that have suffered setbacks. ${ }^{1}$ Sutan Remy states that a debtor may submit a request for bankruptcy statements only if the debtor has stopped paying his debts. Circumstances to stop paying must be an objective situation, because of financial conditions. Debtors have experienced an inability to repay debts. In other words, the debtor is not only unwilling to pay his debts, but his financial objective is indeed in a state of being unable to pay his debts. To determine whether the debtor's finances are already unable to repay debts, insolvency must be determined objectively and independently. This can be done based on financial audits, or financial due diligence conducted by an independent public accountant. ${ }^{2}$ It shows that the essence of bankruptcy is the state of being unable to pay from the debtor rather than the condition of not being willing to pay the debtor, to show the state of being unable to pay the debtor can be demonstrated by the principle of corporate solvency which will be carried out through insolvency of the company.

The principle of solvency can be applied in Indonesia's bankruptcy law because the Indonesian economy has recognized the principle of corporate solvency. Corporate solvency has become a habit in the Indonesian economic environment. A habit that is continuously carried out by the community and its existence is recognized will certainly be the law for the community, likewise, corporate solvency which is continuously carried out by the community in the economic environment would be regarded as common law for the economic community. Philosophically, there is an injustice situation towards the debtor, especially the debtor who is in a healthy financial condition and has assets far greater than the debt. The financial condition of the debtor and prospective business cannot be used as an excuse for the judge to reject the request for bankruptcy. Within the bankruptcy law of Indonesia, generally occurs only to fulfill the element of the number of creditors more than one and the state of default (not paying) one debt that is due, then the situation can be filed for bankruptcy, the fulfillment of this element often does not look at the situation of the debtor whether solvent (able to pay) or in-solvency. It is because the basis for accepting or rejecting a request for bankruptcy in Indonesia is based on a simple verification system to the provisions of Article 2 paragraph (1) of Indonesian Bankruptcy Law as regulated in Article 8 paragraph (4) of Indonesian Bankruptcy Law which states "An application for bankruptcy must be granted if there are facts or conditions which are simply proven that the requirements for bankruptcy as referred to in Article 2 paragraph (1) have been fulfilled". Furthermore, in Article 8 paragraph (5) states, "The court's decision on the application for a statement of bankruptcy must be pronounced no later than 60 days after the date the application for the statement of bankruptcy is registered". The provisions of Article 8 paragraph (4) relating to simple verification which only

\footnotetext{
${ }^{1}$ Hadi Subhan, Hukum Kepailitan : Prinsip, Norma, dan Praktik di Peradilan, Kencana Prenada Media Group, Jakarta, 2012, p. 1

${ }^{2}$ Sutan Remy Syahdeini, Hukum Kepailitan : Memahami Undang-Undang No. 37 Tahun 2004 Tentang Kepailitan, Pustaka Utama Grafiti, Jakarta, 2009, p. 52.
} 
relies on the provisions of Article 2 paragraph (1) relating to the requirements for whether or not a bankrupt debtor actually contains very lenient rules for submitting a request for bankruptcy statements because there is no test of whether a debtor has actually been in a state not able (insolvency test). This is negligence of law makers. Provision Indonesian Bankruptcy Law did not provide a detailed explanation of the procedure for applying this simple proof carried out in examining the request for bankruptcy. The absence of definitions and clear boundaries in the use of simple evidences thus opening wider differences among judges in interpreting the notion of simple substantiation in completing bankruptcy requests. ${ }^{1}$

Ricardo Simanjuntak states that Indonesian Bankruptcy Law did not adopt the Insolvency Test system, because to be categorized as being in a state of insolvency, the company which is going bankrupt must lose money continuously and the capital will be eroded to exceed 50\% (percent), according to this condition, Indonesia only adheres to the assumption of not being able to pay, this assumption was built with legal allegations that are reflected in Article 2 Paragraph (1) of Indonesian Bankruptcy Law. ${ }^{2}$

Jerry Hoff describes that bankruptcy standards formulated by Law no. 4 years 1998, which is now regulated in Article 2 paragraph (1) of Law No. 37, 2004, which is a refinement of the old Bankruptcy Law namely Faillisement Verordening, which uses insolvency standards for bankruptcy statements. He also argues that Article 1 paragraph (1) of Law No. 4, 1998 was the standard for being unable to pay debt. This standard is easier compared to the standard used in the old law. ${ }^{3}$

Regulation about Failisemen did not provide clear definition about failisemen and dan only provide conditions for making requests failisemen, which is that someone has stopped paying. Stop paying is if the debtor is unable to pay or does not want to pay, and has really stopped to pay, but if he/she at the time the bankruptcy application is filed is in a state of being unable to pay the debt (Bandung High Court Judgment No. 171/1973/Perd.PTB. 31 ${ }^{\text {st }}$ July 1973). ${ }^{4}$

According to Ricardo Simanjuntak, not paying debts can be assumed as assumed not able to pay which resulted in the court declaring bankrupt status to the debtor. However, if the debtor is still capable, based on Article 144 of Indonesian Bankruptcy Law, the debtor can submit a peace proposal, if the peace is agreed by the creditors, the debtor will not go bankrupt. This provision is the same as the Dutch Bankruptcy Law (Netherlands Insolvency $A c t$ ). This provision is the same as the provisions of Singapore's bankruptcy law where the debtor's inability to repay debts does not have to be proven but can be assumed as not able to pay. Which means, the Singapore High Court can impose bankruptcy on the basis that the debtor has a debt that is due and can be billed, even if it has been reprimanded (statuary demand) to pay off the debt, but the debtor did not pay it off. With this fact it is assumed to be unable to pay. Statutory demand is used as the standard to determine bankruptcy in Singapore. ${ }^{5}$

Non-regulation of insolvency testing to determine bankruptcy in Indonesia is related to the principle actori incumbit probitio which is adopted in the law of Indonesia. This principle is implemented in Article 163 HIR which stated whoever postulates the rights must prove the existence of those rights. In accordance to this regulation, Ricardo Simanjuntak states that civil procedural law in Indonesia adheres to the principle actori incumbit probitio so that if the insolvency test is applied, the applicant for bankruptcy must be able to prove that the insolvency bankruptcy is in an insolvency state. The above conditions will be more complicated if the applicant is unable to access the respondent's financial statements.

According to Susanti Adi Nugroho, the conditions for someone to file for bankruptcy status is very easy for creditors. Moreover, the evidence in deciding bankruptcy application is a simple verification. Bankruptcy requirements in Indonesian Bankruptcy Law was deliberately made to facilitate its application so that it is hoped that this institution will be more effective in debt collection and Indonesia can get out of the economic crisis as soon as possible. ${ }^{6}$

Regarding the reasons for the lack of insolvency test in bankruptcy law in Indonesia, Hadi Subhan also expressed his opinion that insolvency test, such as preliminary examination at the State Administrative Court, is not really needed in bankruptcy law in Indonesia. There are two reasons underlying his view. First, the legal structure is very difficult to collect debt if by using a default lawsuit. The time can be very long and decisions that are legally binding are still difficult to execute. Secondly, it is very easy to be indebted culturally in Indonesia to other parties. "For the balance of culture in Indonesia where debt is permissive, the law must be repressive. That is why in Indonesia do not use insolvency test"?

\footnotetext{
${ }^{1}$ Aria Suyudi, Eryanto and Herni Dri Nurbayanti, Kepailitan di Negeri Pailit, Pusat Studi Hukum dan Kebijakan Indonesia, Jakarta, 2004, p. 148

${ }^{2}$ Ricardo Simanjuntak at Maruli Simalango, “Asas Kelangsungan Usaha(Going Concern) Dalam Hukum Kepailitan Indonesia”, Journal, downloaded from https://media.neliti.com/ media/publications/164468-ID-inkonsistensi-persyaratan-permohonan-pai.pdf, p. 55

${ }^{3}$ Jerry Hoff, Undang-Undang Kepailitan di Indonesia, Tatanusa, Jakarta, 2000, p.1.

${ }^{4}$ E. Suherman, Failissement (Kefailitan), Binacipta, cet. Pertama, Bandung, 1988, p. 5

${ }^{5}$ Ricardo Simanjuntak, Teknik Perancangan Kontrak Bisnis, Kontan Publishing, Jakarta, 2011, p. 297

${ }^{6}$ Susanti Adi Nugroho, Hukum Kepailitan Di Indonesia Dalam Teori Dan Praktek Serta Penerapan Hukumnya, Kencana Prenada Media, Jakarta, 2018, p. 48

${ }^{7} \mathrm{https}$ :/www.hukumonline.com/berita/baca/lt59flabb87e6fe/gagasan-insolvency-test-tidak-relevan-untuk-revisi-uu-kepailitan/
} 
The non-regulation of insolvency testing in bankruptcy law in Indonesia is closely related to the evidence system in the Bankruptcy Law of Indonesia applying the principle of simple verification. Evidence in a simple manner commonly referred to as a summary proof. ${ }^{1}$ Simple proof is an absolute requirement that limits the authority of the commercial court in an effort to prove whether a debtor who has applied for bankruptcy is proven to have at least one debt that is due and collectible, and the debtor cannot repay his debt which is due and collectible the. ${ }^{2}$ Regarding simple proof, Sudargo Gautama asserted, when heeded the provisions of simple verification, the bankrupt statement was very easy to obtain. Even the request for bankruptcy must be granted and cannot be denied, if the provision is seen literally (letterlijk). ${ }^{3}$

The existence of a simple proof of principle in bankruptcy law in Indonesia is the reason for not implementing insolvency testing in Indonesia. The provision to prove in advance that a debtor is truly insolvent or commonly called insolvency test will result in bankruptcy applicants being burdened with the obligation to prove that the business of the respondent has collapsed, the capital is below 50 percent, and continues to be eroded by debt. This problem will be proven in the initial examination, a kind of dismissal process in the State Administrative Court. The existence of insolvency tests will make the proof no longer simple because it still has to be done in several stages.

\section{Legal Protection of Solvent Debtors that Hold Good Will}

In bankruptcy cases, debtors who are not in good faith are often found. There are some frauds that are commonly done by debtors. First, debtors who have bad intentions to make some debt and then divert their wealth or even hide their wealth, the debtor hopes to avoid paying his debt. Second, the debtor conspires with other parties to create fictitious debts. Third, misusing bankruptcy statements as camouflage in order to cover up bad intentions by transferring capital and wealth to the newly formed company. ${ }^{4}$

Good intention in this bankruptcy case is not only in the form of "intention" or "desire" but the intention and desire are manifested in the form of concrete actions in the form of things that lead to paying debts of debtors to creditors. Based on Ridwan Khairandy good faith exist in subjective and some are objective. ${ }^{5}$. In Article 1338 of the Civil Code it is stated that an agreement must be implemented in good faith. So good faith can be seen from two aspects namely; subjective aspects where good faith is still "intent" or "will" or and objective aspects, where good faith is an "act" or "action" that can lead to legal relations.

Things that need to be considered in a bankruptcy case are bad intentions that come not only from debtors but also from creditors. The bankruptcy process is used by creditors who have bad intentions to threaten debtors who do not want to pay their debts, not because they cannot (unable) to pay debts, even the value of the bill is not proportional to the value of assets owned by the respondent, because in the Bankruptcy Law in Indonesia, there is no minimum debt requirement that is the basis for filing bankruptcy requests.

One of the objectives of bankruptcy law as mentioned above is to protect honest and good-faith debtors from their creditors. Debtors who are considered as still have prospects and good faith in continuing their business can get new financial assistance so they can continue the company again. This is because the inability of the debtor to pay debts is not always due to the debtor's own mistakes and if the debtor is given the opportunity to be able to get back on his business and be able to pay off his debts.

Debtors with good intentions in bankruptcy are debtors who do not abuse the state of bankruptcy as a means to benefit themselves, willing to open honestly about the existence of all his assets and other debts as well as being cooperative in trying to repay his debts. Therefore, although classified as modern bankruptcy law, the perpetrators of bankruptcy fraud who intentionally use bankruptcy to benefit themselves or others are still considered a crime against property and sentenced to criminal. ${ }^{6}$

According to Mulyani Zulaeha, good intentions of the debtor in bankruptcy can be in the form of honesty, propriety and cooperative actions of the debtor in the implementation of the agreement, the actions of the debtor that do not harm the creditor. The form of good faith in the bankruptcy process can also be shown by the attitude of the openness of the debtor to show the company's assets and the ability to produce their business. The application of the principle of good faith in bankruptcy is intended so that one party and the other party will not cheat one another. For instance, the debtor does not do the forgery bookkeeping, the debtor does not run away so that his whereabouts are no longer known, the debtor does not take the action of transferring assets to another party or the debtor does not hide the facts regarding his financial statements. ${ }^{7}$

\footnotetext{
${ }^{1}$ Victorius M. H. Randa Puang, "Penerapan Asas Pembuktian Sederhana Dalam Penjatuhan Putusan Pailit", Tesis, Magister Kenotariatan Universitas Sumatera Utara, Medan, 2006, p. 3

${ }^{2}$ Emmy Yuhassarie, ed., "Undang-Undang Kepailitandan Perkembangannya”, Proceeding, Rangkaian Lokakarya Terbatas Masalah-Masalah Kepailitan dan Wawasan Hukum Bisnis Lainnya, Pusat Pengkajian Hukum, Jakarta, 2005, p. 52.

${ }^{3}$ Sudargo Gautama, Komentar Atas Peraturan Kepailitan Baru Untuk Indonesia (1998), Citra Aditya Bakti, Bandung, 1998, p. 31

${ }^{4}$ Victor Situmorang \& Hendri Soekarso, Pengantar Hukum Kepailitan Di Indonesia, Rineke Cipta, Jakarta, 1994, p. 13.

${ }^{5}$ Ridwan Khairandy, Itikad Baik dalam Kebebasan Berkontrak, Pasca Sarjana FH-UI, Jakarta, 2003, p. 8

${ }^{6}$ Elyta Ras Ginting, Hukum Kepailitan : Teori Kepailitan, Sinar Grafika, Jakarta, 2018, p. 29

${ }^{7}$ Mulyani Zulaeha, “Konsep Kepailitan Yang Memberikan Perlindungan Hukum Terhadap Debitor Perusahaan Yang Prospektif”, Disertasi,
} 
Debtors who are on the verge of bankruptcy must disclose information to creditors various facts and information. Debtors are required to disclose in full disclosure his/her financial condition to all creditors periodically. Meanwhile, if the debtor is in a condition that can be helped, the debtor is possible to be able to come out respectably from his debt problems. ${ }^{1}$

Up to recently the applicable Bankruptcy Law does not provide a form of preventive legal protection for solvency debtors in good faith before the bankruptcy verdict is handed down. Preventive legal protection ${ }^{2}$ provided $^{2}$ by Indonesian Bankruptcy Law was only given after the bankruptcy ruling through the means of peace. For these conditions the principle of good faith and the principle of solvency can be the basis for debtors who are actually still solvent to obtain protection.

The nature of the application of the principle of solvency is to provide legal protection for debtors who are solvent against bad creditors who intend to misuse bankruptcy legal instruments for their own benefit or for the benefit of others, for example creditors who deliberately bankrupt debtors with the intention of getting debtor assets at cheap prices through auctions and others. The use of bankruptcy instruments for purposes that deviate from the nature of the objectives of bankruptcy by parties in bad faith must be prevented by structuring and perfecting the bankruptcy rules themselves.

The principle of solvency should be used as the basis for judges when deciding to file for bankruptcy requests. Before deciding on a case, the Panel of Judges must first assess the debtor's business whether it is feasible to be bankrupt or still be corrected. This has coherence with the provisions of Article 1131 of the Civil Code which places the assets of bankrupt debtors as general collateral for creditors, thus, it will become philosophically irrelevant if the actual debtor is still solvent but then bankrupt. It is closely related to the condition that with bankruptcy if the amount of debtor's assets is greater than the debts, there will not be a struggle for debtor's property by creditors because with a larger amount of assets will guarantee all creditors get repayment.

Changes in mindset and analysis from the judges of Commerce in this case are absolutely necessary in order to provide legal protection for solvency debtors in good faith. The legal protection can be implemented in a way that the commercial judge is not too rigid in applying the bankruptcy requirements stipulated in Article 2 paragraph (1) of Indonesian Bankruptcy Law, but in deciding on a bankruptcy case the commercial judges must also explore the values of justice, fairness and propriety that exist in society.

The existence of Article 8 paragraph (6) of Indonesian Bankruptcy Law should provide a gap for the Commercial Court Judge to make a legal breakthrough, namely by applying unwritten legal provisions but it is considered capable of providing justice for both parties who are in conflict. Strictly Article 8 paragraph (6) letter a of Indonesian Bankruptcy Law states: "The Court's decision as referred to in paragraph (5) must also contain: ... a. Certain articles of the relevant legislation and / or unwritten legal sources are used as the basis for hearing;"

If this provision is associated with the provisions of Article 5 paragraph (1) of Law No. 48, 2009, which states that judges and constitutional judges are required to explore, follow and understand, the legal values and a sense of justice that lives in society, then by law the judge is assigned the task as legislator judgé $e^{3}$ then in fact the application of the principle of solvency of simple proceedings in cases etc. in the corridor for bankruptcy requests can still be carried out using the provisions of Article 8 paragraph (6) without the need to change the provisions of the articles in Indonesian Bankruptcy Law.

The above construction is a suggestion to provide repressive legal protection for debtors. In its proof, the debtor's good faith must be proven by the Judge as long as there is a refusal from the debtor on the request for bankruptcy filed by the creditor because he is still solvent, so in addition to the debtor must prove his solvency, The judge must also prove the debtor's good faith, measured by the ratio of his debt to assets.

\section{CONCLUSION}

The philosophical basis for not implementing the test insolvency in the bankruptcy law in Indonesia are, first, the evidence in a civil case in Indonesia is borne by those who postulate the existence of a right. In this case it is not easy to prove that the debtor is in an independent condition if the debtor is not a public company. Second, it is quite easy to owe in Indonesia so that if insolvency tests are applied in Indonesia it will potentially harm many creditors because the proof can no longer be done simply.

The Bankruptcy Act in force in Indonesia does not provide a form of preventive legal protection for solvency debtors in good faith before the bankruptcy verdict is issued. Legal protection for solvent debtors who hold good faith can be obtained repressively by proving before the trial that the debtor is still in a solvent condition. In its

Program Studi Doktor Ilmu Hukum, Fakultas Hukum, Universitas Brawijaya, Malang, 2016, p. 63

${ }^{1}$ Zulkarnain Sitompul, Pola Penyelesaian Utang Tantangan Bagi Pembaruan UU Kepailitan, Paper, presented at Lokakarya Mengenai Rancangan Perubahan UU Kepailitan, Medan, Desember 2001 Collaboration between FH-UI, Postgraduate USU and University of South Carolina.

${ }^{2}$ Hatta Isnaini Wahyu Utomo, "The Position of Honorary Council of Notary in Coaching Indonesian Notaries", Journal of Law, Policy and Globalization, Vol. 92 (2019), DOI: 10.7176/JLPG/92-12, p. 117

${ }^{3}$ Romli Atmasasmita, Teori Hukum Integratif. Rekonstruksi Terhadap Teori Hukum Pembangunan dan Teori Hukum Progresif, Genta Publishing, Jakarta, 2012, p. 39 
proof, the debtor's good faith must be proven by the Judge insofar as there is a refusal from the debtor on the request for bankruptcy filed by the creditor on the grounds that he is still solvent, so in addition to the debtor must prove his solvency, the Judge must also prove the debtor's good intentions, measured from the ratio of his debt to assets.

\section{BIBLIOGRAPHY}

Asyhdie, Zaeni. Hukum Bisnis “Prinsip dan Pelaksanaannya di Indonesia”, Raja Grafindo Persada, Jakarta, 2005. Atmasasmita, Romli. Teori Hukum Integratif. Rekonstruksi Terhadap Teori Hukum Pembangunan dan Teori Hukum Progresif, Genta Publishing, Jakarta, 2012

Gautama, Sudargo. Komentar Atas Peraturan Kepailitan Baru Untuk Indonesia (1998), Citra Aditya Bakti, Bandung, 1998

Ginting, Elyta Ras. Hukum Kepailitan : Teori Kepailitan, Sinar Grafika, Jakarta, 2018

Hoff, Jerry. Undang-Undang Kepailitan di Indonesia, Tatanusa, Jakarta , 2000

Irawan, Bagus. Aspek-aspek Hukum Kepailitan, Perusahaan, dan Asuransi, Alumni, Bandung, 2007

Khairandy, Ridwan. Itikad Baik dalam Kebebasan Berkontrak, Pasca Sarjana FH-UI, Jakarta, 2003

Nugroho, Susanti Adi. Hukum Kepailitan Di Indonesia Dalam Teori Dan Praktek Serta Penerapan Hukumnya, Kencana Prenada Media, Jakarta, 2018

Puang, Victorius M. H. Randa."Penerapan Asas Pembuktian Sederhana Dalam Penjatuhan Putusan Pailit", Tesis, Magister Kenotariatan Universitas Sumatera Utara, Medan, 2006

Simalango, Maruli. “Asas Kelangsungan Usaha(Going Concern) Dalam Hukum Kepailitan Indonesia”, Journal, downloaded from https://media.neliti.com/ media/publications/164468-ID-inkonsistensi-persyaratanpermohonan-pai.pdf

Simanjuntak, Ricardo. Teknik Perancangan Kontrak Bisnis, Kontan Publishing, Jakarta, 2011

Sitompul, Zulkarnain. Pola Penyelesaian Utang Tantangan Bagi Pembaruan UU Kepailitan, Paper, presented at Lokakarya Mengenai Rancangan Perubahan UU Kepailitan, Medan, Desember 2001 Collaboration between FH-UI, Postgraduate USU and University of South Carolina.

Situmorang, Viktor and \& Soekarso, Hendri. Pengantar Hukum Kepailitan Di Indonesia, Rineke Cipta, Jakarta, 1994

Subhan, Hadi. Hukum Kepailitan : Prinsip, Norma, dan Praktik di Peradilan, Kencana Prenada Media Group, Jakarta, 2012, p. 1

Suherman, E. Failissement (Kefailitan), Binacipta, cet. Pertama, Bandung, 1988

Sulaiman, Robintan and Prabowo, Joko. Lebih Jauh Tentang Kepailitan, Delta Citra Grafindo, Karawaci, 2000

Suyudi, Aria. Eryanto and Nurbayanti, Herni Dri. Kepailitan di Negeri Pailit, Pusat Studi Hukum dan Kebijakan Indonesia, Jakarta, 2004

Syahdeini, Sutan Remy. Hukum Kepailitan : Memahami Undang-Undang No. 37 Tahun 2004 Tentang Kepailitan, Pustaka Utama Grafiti, Jakarta,

Utomo, Hatta Isnaini Wahyu. "The Position of Honorary Council of Notary in Coaching Indonesian Notaries", Journal of Law, Policy and Globalization, Vol. 92 (2019), DOI: 10.7176/JLPG/92-12

Utomo, Hatta Isnaini Wahyu., "The Existence of the Notary and Notarial Deeds within Private Procedural Law in the Industrial Revolution era 4.0", International Journal of Innovation, Creativity and Change, Volume 10, Issue 3, 2019

Widjaja, Gunawan. Tanggung Jawab Direksi atas Kepailitan Perseroan, Raja Grafindo Persada, Jakarta, 2003

Yuhassarie, Emmy. "Undang-Undang Kepailitandan Perkembangannya", Proceeding, Rangkaian Lokakarya Terbatas Masalah-Masalah Kepailitan dan Wawasan Hukum Bisnis Lainnya, Pusat Pengkajian Hukum, Jakarta, 2005

Zulaeha, Mulyani. "Konsep Kepailitan Yang Memberikan Perlindungan Hukum Terhadap Debitor Perusahaan Yang Prospektif”, Disertasi, Program Studi Doktor Ilmu Hukum, Fakultas Hukum, Universitas Brawijaya, Malang, 2016 